\title{
THE CITIZEN'S RIGHTS AGAINST THE MODERN STATE AND ITS RESPONSIBILITIES TO HIM
}

\section{SIR GUY POWLES*}

This subjects falls, of course, to be discussed in the framework of a free society, and in our part of what we are accustomed to call the free world. It is a matter which vitally concerns individual human freedom.

It is as well to recall some basic concepts and emotions before embarking upon a more intellectual examination. The word "freedom" is a fascinating word; it is a truly emotive word-in any society, and at almost any stage of its development, this word arouses and has aroused complex emotions, some of them most intense. At the same time it is a somewhat tired word. It has been overworked-and perhaps nowadays we have heard so much about it that we are too readily inclined to pass it by and think about something else. Yet no one who has heard thousands of people calling out for it, calling out for freedom-whether it is "Mrdeka", or "Uhuru", or just "free-dom" "free-dom"-can ever overlook or forget how vital these concepts are to the very core of human life and society. For centuries this word, and all that from time to time people understand it to mean, and to imply, has been a banner under which men and women have fought and died, have suffered hardships and tortures, and have purged their souls. I believe, therefore, that in our affluent societies, wrapped up in our welfare States, we tend to take freedom too much for granted.

I suggest it is salutary to note that this discussion is one of Rights and not of Liberties. Within this century, and almost since the countries under the Southern Cross achieved nationhood, we have seen a marked change sweep over these concepts. The thinking of Mill, and of Dicey, mirrored the outlook of the Victoria era, and influenced all generations up to our own. Mill said: -

"The only freedom which deserves the name, is that of pursuing our own good in our own way, so long as we do not deprive others of theirs, or impede their efforts to attain it."t

Yet, when President Roosevelt spoke of the "Four Freedoms" some years ago, many people thought that he was offering a fine summary of the kind of liberties that a democratic people could cherish as the basis of their society. One of these was styled, "Freedom from Want" and another "Freedom from Fear". Neither of them is freedom in the older sense-the right of the individual not to be interfered with by the power of society. On the contrary, they are claims of the individual to be dependent upon society. There is nothing in itself derogatory in the notion of dependence. There is dependence in the highest form of human relationships, just as in the lowest form of life. The citizen is now dependent upon the State; the two are intertwined, the one created

- K.B.E. C.M.G.. E.D., LL.B.. Parliamentary Commissioner (Ombudaman) lor New Zealand. This article has also appeared In the March 1964 number of the Australian journal, Public Administration, and appears here with the kind permisston of the editor of that journal. The artlele is a revised version of an address given by Sir Guy Powles to the Royal Institute of Public Administration, Canberra, November 1963 . IMill. Escay on Liborty 11 (1859). (Blackwell ed. Oxford 1948.) 
by the other, forming a complex social, political, and economic structure bound together by numerous ties of mutual welfare.

Indeed we have seen come to pass what Mill foresaw, when he used these prophetic words: -

"The disposition of mankind, whether as rulers or as fellow eitizens, to impose their opinions and inclinations as a rule of conduct on others, is so energetically supported by some of the best and by some of the worst feelings incident to human nature, that it is hardly ever kept under restraint by anything but want of power; and as the power is not declining, but growing, unless a stronger barrier of moral conviction can be raised against the mischief, we must expect, in the present circumstances of the world, to see it increase."1a

This is what has actually happened, and today a modern authority, Professor H. W. R. Wade, can say:-

"During the last hundred years the conception of the proper sphere of governmental activity has been completely transformed. Instead of confining itself to defence, public order, the criminal law, and a few other general matters, the modern State also provides elaborate social services and undertakes the regulation of much of the daily business of mankind. The State has seized the initiative, and has put upon itself all kinds of new duties. In order to carry out so many schemes of social service and control, powerful engines of authority have to be set in motion. To prevent them running amok there must be constant control, both political and legal. Ultimately the political control rests with Parliament, though in reality much power is in the hands of ministers and officials. The legal control is the task of the Courts of law.2

Yes, the State has pervasive power. This power forces the citizen to assert his rights. He is on the defensive. He feels the possibility of being smothered by authority. Thus we talk now of rights, of Bills of Rights, the Universal Declaration of Human Rights, and not so much of civil liberties any more. Any reference to the State, as if it were a separate entity-a Leviathan apart-is only an ideological convenience. The State is, of course, a pure abstraction: it does not feel pleasure or pain, it has no hopes or fears, and what we think of as its purposes are really the purposes of the individuals who direct it. When we think concretely, not abstractly, we find, in the place of the 'State', certain people who have more power than falls to the share of most men. Furthermore, there is a Parkinsonian imperialism at work. "Since it is natural to energetic men to love power, it may be assumed that officials in the majority of cases will wish to have more power than they ought to have."3

Whatever conceptual arguments there may be about the State, there is no doubt about the power, and the average citizen is clearly and uneasily aware of it. This awareness is typified by the query of one of my clients in a plaintive letter to me:-

"Is it lawful to put me in such a position that I have to go to law to prevent damage to my property when it is the task of the law to protect my property?"

There are the twin aspects of State power, legislative power, and executive power, and some authorities add a third, the Police power." The traditional methods of control of power are political and legal, and it is significant that there have recently been attempts to polish and sharpen these old tools in order to enable them to be more effective in dealing with the powerful and complex administrative jungles of today.

\footnotetext{
1a $i d$. at $12-13$

2 Wade, Administrative Laro 1 (1961).

3 Russell, Authority and The Individual (1949).

+ McDermott, Protection from Power under Engltoh Law (1957).
} 
On the political side, I should note, before proceeding any further, that the unicameral legislature and the bare constitutional structure of New Zealand provide a classic example of the supreme and unfettered sovereignty of Parliament.

It is said that, now that executive and legislative power are to all intents and purposes the same, because both powers have fallen into the same hands, the hands of the ruling political party, our fundamental rights do not seem so secure as they were in the past. The security of our ancient rights is becoming a frail thing." All our rights can now be regarded as having been granted by Parliament, and they can thus be added to, altered, or taken away by Parliament. Great words such as constitutional rights, liberty, and the rule of law, seem to change their meaning even while one looks at them.

It is not my purpose to criticize such a situation, but merely to set it out as fact; although, having drawn your attention to it, I feel bound to observe that the supremacy of Parliament is useful in this modern age, in that it provides a substantial degree of flexibility and room for manoeuvre in the rapidly changing conditions of today; it is highly sensitive to public opinion when that opinion becomes reasonably formed and vocal; and it gives to the citizen his ultimate, and perhaps some would say his only, real right, which is to exercise his choice at the ballot box on somewhat infrequent occasions.

In New Zealand there are those who are not prepared to accept blindly this unfettered supremacy of Parliament, and there is much active discussion about methods of fettering it in some way or other. The New Zealand Constitutional Society presented to Parliament in this last session a petition containing 10,000 names and asking for the establishment of a second Chamber, the idea being that the presence of a second Chamber would in some way produce more balance and deliberation in the exercise of the power of Parliament, and might serve as a buffer between the citizen and the supposedly power-hungry activities of the executive-ridden lower House. Furthermore, pursuant to a previous election promise, the Attorney-General has introduced as a policy measure a Bill of Rights, and this Bill has been referred to the same Special Committee to which has been referred the Petition for a second Chamber. I give these to you as instances of activities by citizens designed to protect what they conceive to be their rights and to carry out this protection in the political field.

A discussion of a citizen's rights against the State is really one of the procedures and methods whereby a citizen may assert his claims to an individual existence, to have at least some things which he holds dear kept inviolate and subject to his own will and not to the collective will of others. These things, these fundamental rights, are well summed up, according to one view, in the first clause of the draft New Zealand Bill of Rights as follows: -

"(1) It is hereby recognized and declared that in New Zealand there exist and shall continue to exist, without discrimination by reason of race, national origin colour, religion, opinion, belief, or sex, the following fundamental human rights and freedoms, namely:

(a) The right of the individual to life, liberty, and security of the person, and the right not to be deprived thereof except in accordance with law:

o Radellte, The Problem of Power (1951). 
(b) The right of the individual to equality before the law and to the protection of the law:

(c) The right of the individual to own property, and the right not to be deprived thereof except in accordance with law:

(d) Freedom of thought, conscience, and religion:

(e) Freedom of speech and expression:

(f) Freedom of peaceful assembly and association." $s_{a}$

The other view is that this list does not, in the second half of the twentieth century, and in the light of the Universal Declaration of Human Rights, go far enough. It fails, for example, to include all that bundle of rights known as Social Security, and covered by Freedom from Want and Fear, which may be just as fundamental to our scheme of society as, say, freedom from arbitrary arrest or the right of free assembly, which are two rights always spoken of as "constitutional" and originating in our common law."

There is another right which does not fall within these classes, but arises as a corollary to the freedom of thought, conscience and religion, and of speech and expression. This is the right to know." An informed public opinion is necessary for the maintenance of our democratic system. Basically, a citizen has a right to know how his affairs are conducted by his elected representatives, what goes on in his courts of justice, and what decisions affecting him are made by his bureaucracy. This right is subject to legitimate qualifications, the extent of which has been the subject of much recent controversy in New Zealand.'

But the important question is the protection of these rights, against power, against State power, and this is a question of legal procedure; just as the classic right to the Writ of Habeas Corpus is in form but a procedural right, enabling the enforcement of the right of personal freedom. This famous writ effectively succeeded in its purpose because of the fluidity and ease with which it could be sought and obtained-it could be granted by any Judge, and if one Judge refused it application could be made to another-and it is unique in having this procedural facility expressly preserved in New Zealand today. One might perhaps hope that other remedies could have similar advantages.

I suggest, therefore, that one of the most important responsibilities the State has to the individual citizen is to provide adequate, efficient, and effective mechanisms for the enforcement of his rights, even if this enforcement may be sought against the State itself. This responsibility is not weakened by the possible impermanence of those rights. The fact that Parliament could, in New Zealand, abolish the right to Habeas Corpus tomorrow, if it wished to, is no argument against the advantages of simple and effective procedures for obtaining this Writ as long as it can be lawfully obtained. Similarly, the fact that Parliament is supreme, and can bend and mould to its will the whole administrative structure of the State is no argument against the responsibility to see that simple and effective procedures are available to all citizens who become entangled in the administration.

Then there are, on the political front, important ways whereby citizens can assert their rights against the State.

6 tbid.

on [Cl. The Canadlan Bll at Rights, $8-9$ Fliz. 2 c. 44 s. 1.-Ed.]

- Burns, Address to Commonwealth Press Union (N.Z.) July $3,1960$.

7 Public Bodles Meetings Act, 1962. Indecent Publications Act, 1963. 
One such method, for example, which is by no means lightly to be dismissed, is the right of a member of Parliament to ask a question on the floor of the House, and such a question is frequently associated with some injustice of which a particular constituent has complained. Here is a direct thrust by the Legislature into the territory of the Executive. On the floor of the House the Minister is usually expected to support his department, but in the process of advising Ministers on their answers the organs of the administration are sometimes compelled to reconsider dubious decisions. Questions can have a salutary influence in calling attention to injustices, but not necessarily in righting them.

Then again every citizen has in New Zealand the right to petition Parliament, sometimes referred to as "a right to appeal to the highest Court in the land". There are numbers of these petitions lodged every year, and they are heard by appropriate Committees of the House. Petitions cover a wide field: routine matters of standing orders relating to private legislation, suggestions for amendments to current laws, questions of important public interest about which the petitioners wish to agitate, and applications for redress of individual wrongs. It is this last class which interests us and a study of the history of New Zealand Petitions to Parliament in recent years shows that this is the class that fares worst. The House normally endorses the Committee's verdict, which may be "No Recommendation", "For Consideration", "For Favourable Consideration", or "For Most Favourable Consideration"; it is only the last upon which a Government may be expected to act, and it does not always do so. In one recent period of seven years one student $^{3}$ found that of 303 petitions presented 47 received "Most Favourable Recommendation", and, even after that, if the claim was for monetary compensation the chances were three to one against the petitioner receiving any recompense. In the last five years, out of 253 petitions 17 received a "Most Favourable Recommendation", the Govermment gave substantial effect to six of these recommendations (including four cases where monetary grants were made), four recommendations were met in part, and seven cases resulted in no ascertainable benefit to the Petitioner. Of course, it must be emphasized that no Petition to Parliament for compensation or redress to an individual may be presented unless the petitioner has exhaused his legal remedies, so that petitions in such a case become a last resort-a forlorn hope. Even then the numbers of those which receive fullest Parliamentary support but fail to secure Governmental action are the cause of uneasiness in political circles and frustration amongst the citizens.

Then finally, and still on the political side, every citizen may complain to his Member of Parliament, and he frequently does this when he believes that his rights have been infringed by some State action. The Member of Parliament then goes to the Minister concerned, and the Minister communicates with his departmental head and asks for a report upon the complaint. Down it goes through channels in the department, and then up again to the departmental head, who is, as a rule, concerned to find no justice in the complaint, and drafts for the Minister to sign a letter saying so at some length but with less precision. This letter is then sent by the Minister to the Member of Parliament, who then informs

8 N.Z. Truth, 16th July, 1957. 
his constituent accordingly. This procedure is a useful safety valve, and frequently results in a citizen becoming less dissatisfied than previously, but matters tend to be dealt with rather on the surface, in that there is no deep inquiry or verification of the facts or of the departmental attitude. Furthermore, the practice of regarding one's Member as a sort of local "grievance man" is capable of abuse.

The broad principle of political control extends, of course, over the executive. The legislature makes laws of varying degrees of precision and detail, and these laws must be administered by the executive. The Ministers, themselves the ruling group in the legislature, control the administration of these laws in accordance with the policies of the Government of the day, but the classic pattern of ministerial responsibility has its inadequacies as a mechanism of control. All Ministers must rely heavily upon the senior officers in their departments to ensure that the administrative activities are lawful, proper, wise and just.

Passing now from consideration of political methods of control to those of legal methods, I am going to suggest that we find a similar picture of inadequacy, leading to a frustration of the citizen in his endeavour to exert his rights against the State.

With the basic interest that the citizen has in political activities, and with his feeling of involvement in party politics, and of being a democratic voter with rights, it is natural that rather than attack the forms of oppression which may be created by his own Parliament he finds bureaucracy an irresistible target. This, in a sense, is wholesome, but of course, the source of the power and influence of the bureaucrat is statutory, and Parliament has itself created this situation. While the citizen struggles well enough with his political machine, and sometimes succeeds in steering it slightly to his interest, he has more difficulty with the mechanisms of bureaucracy-those powerful engines of authority which, as Professor Wade says, constantly threaten to run amok. "What is wrong", said Mr. R. A. Butler" "is that the judicial system-the courts of law, tribunals and inquiries-has not been adapted and extended so as to guarantee full protection to the interests of the individual." It is significant that Professor Wade goes on, after the passage quoted earlier, ${ }^{\text {an }}$ to say that this legal control, together with a few special features of political control, provides the principal subject matter of administrative law, and yet we find that in the most respected Court of English Law, the House of Lords itself, in this year 1963, a most learned Lord said: ${ }^{10}$

"We do not have a developed system of administrative law-perhaps because until fairly recently we did not need it."

The citizen's search thus tends to go beyond the Courts to seek ways of protecting himself and asserting his rights.

What we do have now is not a developed system of administrative law, but a hodge-podge of ancient methods reluctantly adapted to new tasks, together with a plethora of ad hoc tribunals and other authorities. The courts have built a system out of the old bits and pieces, while perhaps feeling that it is not quite respectable to do so. The old Writ of Mandamus presupposed the existence of a legal duty to act, which is not

9 (U.K. 1958) 590 H.C. Deb. 1614-15.

10 Rldoe v. Baldtoin [1963] 2 All E.R., 66, 76 per Lord Reld. 
very useful when one wishes to challenge the exercise of discretion by an administrative official. The writs of prohibition and certiorari are not so limited, but they were originally designed to control the activities of inferior courts, and were extended to the acts of administrative officials when these officials could be said to have a duty to act judicially, sometimes a circumstance difficult to establish. The writ of injunction is bound up with rights of property. We are left with the declaration (the declaratory judgment) which is a comparatively modern remedy. It is no more than an official statement by the Court that a certain course of action is lawful, or unlawful. It could perhaps be a valuable procedure for the citizen, but the Courts have determined to use this tool sparingly and with caution.11

As an indication of these procedural complications, we find that over the last ten years in New Zealand the significant reported cases on administrative law where rectification of grievances was sought numbered 56, and these were procedurally divided as follows: -

Mandamus, issued 3, refused 4;

Certiorari, issued 6, refused 8;

Prohibition, issued 1, refused 2;

Injunction, granted 1 , refused 2;

Declaration, made 2, refused 6;

Others (actions, cases stated etc.) succeeded 11, failed 10.

In addition to being complex and tricky, these procedures are also slow and expensive, points which need no elaboration.

Even then, having put up the money for his costs, and having got his case into Court, the citizen may find that the principles on which the Courts act will not give him complete satisfaction. The Courts will not in general review the substance of an administrative decision-they will say whether the decision is lawful or unlawful; they will not say whether it is right or wrong. As de Smith says:-

"Even in countries where judicial review extends more broadly and penetrates more deeply than in England, review normally stops short at the frontier between control over the legality of administrative action and full re-examination of the merits of administrative action. The depth of judicial review is determined primarily by the demarcation of that frontier. In England the frontier has been set along a line which leaves the Administration with a vast area of legislative and executive discretion effectively shielded from judicial scrutiny."

When the Courts so act, however, they will in general submit the decision complained of to a procedural scrutiny to determine whether or not it has been arrived at in accordance with the principles of natural justice; two fundamental considerations being whether the affected party has had an opportunity of being heard in his own defence, or whether the tribunal concerned is improperly interested or biased with reference to the case. Even here, however, it is noteworthy that the English Courts appear to have had, in recent times, a somewhat clouded vision of the most important of these great principles, namely the right to be heard in one's own defence. Some authorities date this principle back to the events in the Garden of Eden where "... even God himself did not pass sentence upon Adam before he was called upon to make his

11 Brett, Administrative Law: A Conceptual or Functional Discipline.

Address to Australasian Iaw Schools Conference, Ausust, 1963.

12 de Smlth, Judicial Review of Adminiotrattve Action, 248 (1959) 
defence. 'Adam', says God, 'where art thou? - Hast thou not eaten of the tree, whereof I commanded thee that thou shouldst not eat?' "12a Adam, of course, was guilty, but he was at least heard and was able to offer a plea in mitigation. It is a far cry from the Garden of Eden to the House of Lords in 1963, when he find that five of the principal legal luminaries of England were engaged in asserting that a Chief Constable of an English town, who had been dismissed by his Watch Committee, should have been given by the Committee an opportunity to be heard before they decided upon his dismissal. This case ${ }^{10}$ may be one of the milestones in this branch of English law, marking the return of the errant English courts to the somewhat purer and straighter path which I am glad to say seems to have been pursued by the Courts in Australia and New Zealand. It is worthy of note, however, that argument in the House of Lords lasted for eight days, that the case had previously been heard in the Court of Appeal and below that in the lower Court, and the cost involved must have been immense.

One cannot help feeling, therefore, that in respect of the judicial review of administrative decisions the State is failing in its responsibility to make adequate procedures available to the citizen. In a recent address, ${ }^{11}$ to which I am indebted for some previous observations, Professor Brett of Melbourne expressed the belief that the first and most crying need is the development of a simple system for getting a case into Court for review, and that this can be done by legislation or even by the Courts themselves. Even he, however, has as his guiding principle that where Parliament has entrusted a particular task to an administrative official or body it is not part of the Court's function to come into the question for a second time, and attempt itself to give a decision on the matter. Thus in no sense would even Professor Brett's greatly facilitated judicial review operate as an effective redress of wrongs, in the sense of a reversal of wrong decisions.

Another aspect of the administrative complex which has become of great importance in these days is the growth and proliferation of the special bodies or ad hoc tribunals. This, of course, has not happened overnight. The seeds of many of these bodies and tribunals were sown in the last, or even earlier, generations. Put in its most general terms, the problem is the problem of reconciling, in the field of administrative action, democratic safeguards and standards of fair play with the effective conduct of Government, and the reasons for the development of administrative tribunals as law-making adjudicatory bodies alongside the ordinary Courts may be briefly summarized as follows:

First the problems they deal with are supposed to be foreign to the regular Courts and can, so it is thought, be better handled by persons with special qualifications. Secondly, the ordinary Courts are slow and cumbersome and are subject to many procedural difficulties, as outlined above. Thirdly, there is the question of the expense involved, and in many cases the citizen's dispute with the State may concern a matter of little monetary value, although of considerable personal importance to him. Fourthly, the volume of work would be such that the ordinary Courts might become seriously overburdened or, if additional Judges 12a [id. at 103 n.. quoting R. v. Chancellor of the University of Cambridge (1723) 1 Str. 
were appointed, the high quality of the judicial bench would be in danger of dilution. ${ }^{13}$

Whatever the reasons, there is no doubt, as Lord Denning said in his Hamlyn lectures, ${ }^{14}$ that the new tribunals in England do constitute a set of administrative Courts, but they have grown up in so haphazard a fashion that it is difficult to fit them into any recognizable pattern. He went on to say that one of the most important tasks of the lawyers of today is to mould these tribunals into a coherent system of Courts which will keep a just balance between the claims of the community on the one hand, and the freedom of the individual on the other. The great need is to work out the principles of procedure which should govern these tribunals. On the other hand, Lord Evershed pointed out that one does not solve the problems of interpretation of the enacted law by the mere expedient of assignment to some specially constituted tribunals, however conscientious and independent. He suggests that the best answer may be in review and reform of the procedure of the ordinary Courts, ${ }^{13}$ a conclusion to which Professor Brett has arrived in another connection, as mentioned above. There is much thought and discussion being given to these points, but as yet, one sees faint result.

At any rate, in New Zealand, these many tribunals have been allowed to multiply somewhat according to rule of thumb, and now it would be a very wise and brave research student who would presume to say just exactly how many of these bodies we have. They operate partly or wholly in the legislative or judicial or administrative fields or in a combination of all or some of these fields. There is a right of appeal from some of them, sometimes to a special tribunal, sometimes to a Court of law. From some there is no right of appeal. There is a right of rehearing in some cases, but not in others. They are nearly all to be distinguished by the presence of a privative clause preventing right of recourse to the Courts of Justice, except in the case of lack of jurisdiction. They do indeed cover a very wide range as the following summary will show-and by no means all the tribunals are mentioned:-

$\begin{array}{ll}\text { Licensing } & \text {-Films, fish, poisons, milk, transport, petrol, alcohol. } \\ \text { Trade } & \text {-Prices, tariff, Imports, restrictive practices. } \\ \text { Social Security } & \text { - Pensions, health. } \\ \text { Land } & \text { - Valuation, settlement, conservation, compensation, forests. } \\ \text { Local Government } & \text {-Reorganization, Town and Country Planning, Loans. } \\ \text { Labour and Industry - Arbitration, Waterfront Control. } \\ \text { State Services } & \text { Workers' Compensation, Shops and Offices. } \\ \text {-Board of Appeal, Government Services Tribunal, Railways, } \\ \text { Miscellaneous } & \text { Post Office, and Police Appeal Boards. } \\ & \text {-Taxation Board of Review. } \\ & \text { Earthquake and War Damage Commission. }{ }^{13}\end{array}$

Finally, we have just produced another-a tribunal on the Censorship of Indecent Publications from which there is a right of appeal to the Full Court of the Supreme Court. This is a tangled web, indeed, and we have not in New Zealand any equivalent of the Council on Tribunals. ${ }^{10}$

Nevertheless, this does show, I think, some important recognition of the responsibility of the State in the matter of the protection of the rights of its citizens. In other words, the legislature does not generally concoct

13 Orr, Administrative Justice in New Zealand (unpublished).

14 Denning. Freedom under the Law (1949).

16 Evershed. The Impact of Statufe on the Law of England Maccabean Lecture, 1956.

10 Tribunals and Inquirles Act, 1958 (Imp.) 6 \& 7 Ellz. 2 c. 6 . 
plans, schemes, and projects, or construct magnificent organs of State administration without making at least some provision for a judicial or semi-judicial consideration of the interests of the citizen. But it is all, most intensely complicated, and it is interesting to note that in the $\mathbf{5 6}$ administrative law cases concerned with the redress of grievances over the last 10 years, mentioned above, more than twice as many of these were directed against these special bodies and ad hoc tribunals as were directed against Ministers and Departments of Government itself. It is not surprising, therefore, that the ordinary citizen feels a little lost in this almost impenetrable jungle. Moreover, there were still wide areas of administration where there was no effective form of review or redress.

It was in these circumstances, therefore, that the idea for the appointment of an Ombudsman fell on fertile ground. There had been no Crichel Down; ${ }^{17}$ no commissions or studies such as had been produced in England under such names as Donoughmore ${ }^{18}$, Franks ${ }^{10}$ and Whyatt"0; and despite two recent and perhaps isolated episodes, ${ }^{21}$ no public concern over the possibility of administrative turpitude of the sort revealed in Odlum v. Stratton ${ }^{22}$; indeed it is fair for me to say now, after a year in office and having received over 700 complaints, that I have as yet found in the New Zealand Public Service no evidence of corruption or moral obliquity-mistakes, carelessness, delay, rigidity, and perhaps heartlessness, but nothing really sinful. The reasons for the general approval of the setting up of the office are to be found in the general feeling of uneasiness and bafflement which I have outlined.

A Citizens' Review Authority appeared in the National Party's election platform in 1960 , and rapidly created substantial interest. The name 'Ombudsman' had the attraction of the unknown. After the National Party was returned to power and at its first session in July, 1961, the question was asked the Attorney-General- "Whether in view of the universal public interest in the appointment of the Ombudsman he would inform the House whether the necessary legislation would be introduced this session." ${ }^{23}$ The answer was in the affirmative, and the Bill was in fact introduced. In doing so the Attorney General stated its purpose as follows: - 24

"The National Party's policy at the election had stated categorically that, to ensure that members of the public in dealing with Departments of State had the right and opportunity to obtain an independent review of administrative decisions, the National Party proposed to establish a Citizens Appeal Authority, and that any person affected by an administrative decision would have the opportunity of having that decision reviewed. The introduction of the legislation would be an attempt to reverse a trend that had been going on for hundreds of years-the whittling away of the individual rights of citizens, and the State coming more and more into the picture in restricting the rights of individual citzens."

The Attorney General could also have said that the establishment of this Office was an attempt to carry out one of the responsibilities of the State towards its citizens, namely to provide them with better means of procedure for the enforcement of their rights. He might then have gone on to suggest that the Office could be regarded as an independent institu-

\footnotetext{
17 Allen, Law and Orders, 343 (2d ed. 1958).

18 (1932) Cmd. (U.K.), 4060.

18 (1957) Cmd. (U.K.), 218.

20 Justice, The Clizen and the Administration (1961).

21 Ministry of Works, Rongotai 1860 and 1961; Thompson v. Turbott [1962] N.Z.L.R. 298.

22 Allen, op. clt. supra, at 427 .

23 (1961) Porllamentary Debates (N.Z.) 811

24 id. at 1244.
} 
tion in the welfare State, where the State itself provided for its citizens an authority which could complain on their behalf against itself.

The Whyatt Report ${ }^{20}$, which Lord Shawcross said could form the basis of what could become a real Charter for the little man, divided citizens' complaints into two main categories-complaints against administrative decisions, which really are appeals on the merits, and complaints against administrative misconduct, which are really accusatory. The Report recommended a form of Ombudsman only for the second class, for maladministration.

It is thus interesting to note that from the outset, the Office in New Zealand has been regarded as established for the purpose, not only of checking administrative abuses and of righting of wrongs, but also of actually reviewing administrative decisions-of securing the making of changes. This is wider than the original purpose of the well-known Danish institution of this name, which was earlier thought of as more of a following control and only developed into a review authority in the course of practice. ${ }^{2 s}$

The Attorney General in introducing the Bill in New Zealand pointed out $^{24}$ that it could not be modelled exactly on the Danish or Swedish types, because the constitutions of these countries differed from that of New Zealand, and it was necessary to draft a concept that suited New Zealand's needs. In actual fact several committees worked on the draft of this Bill, and the resulting Statute shows the evidence of much care and thought, which could itself be at least partly responsible for the favourable reception accorded to the institution.

The Statute setting up the Office of Ombudsman in New Zealand and empowering his activities is the Parliamentary Commissioner (Ombudsman) Act 1962 . The main operative section prescribes that the principal function of the Commissioner is to investigate any decision or recommendation made (including any recommendation made to a Minister of the Crown) or any act done or omitted relating to a matter of administration and affecting any person or body of persons in his or its personal capacity, in or by any of the Departments or organizations named in the Schedule to the Act, or by any officer, employee, or member thereof in the exercise of any power or function conferred on him by any enactment. The departments or organizations named in the schedule to the Act are practically all the Government administrative departments and agencies, but special statutory corporations which are not truly part of the State Administration are omitted. For example, the New Zealand Broadcasting Corporation and the National Airways Corporation are outside the jurisdiction of the Ombudsman. It will be seen that the jurisdiction extends to matters of administration, with the consequence that matters concerning policy only would be excluded. The notoriously difficult distinction between a matter of policy and a matter of administration is thus one which periodically raises its head in the office of the Ombudsman. So far it has not been possible to construct any guiding principles but merely to decide, upon common sense grounds, each case as it arises. The actual level at which a decision is made is not helpful because matters of administration are sometimes decided at the highest levels, even by the Cabinet itself. 
The provisions of the Statute obviously and designedly stop short at giving the Ombudsman authority to inquire into the decisions of Ministers themselves, but any recommendation made to a Minister by a Department or Agency, even if the Minister has already acted upon it, may be inquired into and, if necessary, reported upon, by the Ombudsman. Thus cases have arisen where investigation has disclosed grounds for criticizing a recommendation upon which a Minister has acted, and the Minister has been informed accordingly. The converse case has also occurred, namely where the Minister has deliberately, and after consideration, decided not to accept or act upon departmental recommendation. Fortunately, neither of these types of cases has caused any unsurmountable difficulty or friction, and so far, although of course the office is still a young one, there is no cause to feel that the parliamentary principles of ministerial responsibility are likely to stand in the way of the effective operation of the Ombudsman, or themselves to suffer by reason of his activities.

During the debate on the Bill in the House, the Attorney General, commenting on the provision relating to recommendations to Ministers, said" $^{\text {"0 }}$ "If the Minister follows that recommendation, then criticism of the recommendation will in effect be criticism of the decision. If he does not follow the recommendation then, that fact will doubtless be stated by the Commissioner. In either event the Minister in the light of the Commissioner's findings will eventually be called upon to justify his action in Parliament and that is where the Minister should be called upon to account for his administrative acts."

The Ombudsman's jurisdiction is expressly excluded if there is some right of appeal on the merits of the case to a Court or a tribunal, whether or not that right has been exercised. Neither is there any jurisdiction to investigate acts performed by Government Officials as trustees, nor to look into matters concerning the Armed Services or decisions of the Crown Law Office. Thus, since the actions of the organs of local government and their servants are also omitted from the scope of his authority, the Ombudsman's activities do not by any means cover all acts of administration as it affects the citizen. Furthermore, the Ombudsman is given a discretion to refuse to entertain a complaint if he considers it to be trivial, frivolous, vexatious, not made in good faith, or one in which the complainant has not a sufficient personal interest; and if the complainant has had knowledge of the matter of his complaint for more than 12 months before complaining to the Ombudsman, it may be declined.

The Act prescribes that the complaint must be in writing and accompanied by a fee of $\mathrm{fl}$, and that the investigation must be in private, but, apart from that, there is no statutory regulation of the procedure for the investigation-this is, by design, left to be as informal as possible. Indeed a constant attempt is made in practice to prevent the developing of hard and fast rules of procedure-the main objective being that the complaint should be investigated according to its merits and its substance, guided by a basic principle that, as far as the Ombudsman is concerned, the complainant is deemed to be right until he is proved wrong.

Contacts with the Government Departments and Agencies concerned are also deliberately kept upon an informal basis with the object of

20 (1962) Parllamentary Debates (N.Z.) 1012. 
arriving at the truth of the matter, and of, at the same time, securing and retaining the confident co-operation of senior departmental officials in the righting of wrongs and the remedying of administrative errors. As Prof. Hurwitz, the Danish Ombudsman has said "It is not only necessary for such a one-man show as the Ombudsman to have the confidence of Parliament and the population, it must also have the confidence of the administration".2 The Ombudsman communicates by letter directly with the Head of the Department or Agency concerned and frequently the matter is followed up by personal discussions. The Act gives very complete powers to summon and examine persons on oath, if necessary, and a complete right of access to departmental records and to departmental premises. In practice, the Departments are only too willing to produce their files and papers. The question of what is known as Crown privilege was the subject of much discussion during the drafting of the Bill and was also debated in the House during its passage. The relevant section, as passed, provides that the rule of law authorizing the withholding of documents or information on the ground of public interest shall not apply to any investigation by the Ombudsman unless the Attorney General certifies that disclosure might in the circumstances prejudice the security of New Zealand or the investigation of offences, might involve the disclosure of the deliberations of the Cabinet, or might involve the discloure of any proceedings of the Cabinet relating to matters of a confidential nature and would be injurious to the public interest. The distinction between "deliberations" and "proceedings" is intriguing, and the reference to "Cabinet" is believed to be the only mention in a New Zealand statute of this body by name. In other words, except in very special cases Crown privilege does not apply against the Ombudsman. On the other hand, the Ombudsman is himself required to maintain secrecy in respect of all matters coming before him except so far as disclosure may be necessary to enable him to carry out his duties and to support his recommendations.

Before investigating any matter the Ombudsman is required to inform the head of the department or agency affected and if during his investigation it appears that there may be grounds for an adverse report he is required to give to the department or agency concerned an opportunity to be heard. It is expressly provided that the Ombudsman may not, in any report, make any comment adverse to any person unless that person has been given an opportunity to be heard. The Act contemplates that the Ombudsman should not be too remote from Ministers; that, as the Attorney General put it, the Minister cannot live in an ivory tower with reference to the Ombudsman. Accordingly, the Ombudsman has the right to consult the Minister at any time and must do so in any case where an investigation relates to a recommendation which has actually been made to a Minister. The Ombudsman is also required to send to the Minister concerned a copy of any report or recommendation he may make with reference to a department or agency.

The investigatory procedure involves, in general, the exchange of correspondence with the complainant, and also with the department and others concerned, but complainants are quite often interviewed in person, and of course, so are the departmental heads and officers concermed. It has not been found necessary for the Ombudsman to make any physical 
inspections nor to travel much outside the Capital city. The necessary records, reports, and authority, are available or obtainable in Wellington where by far the major part of his business is transacted.

To turn now to the actual power or authority of the Ombudsman, it should be emphasized at the outset that he has no power to make anything in the nature of an executive order or decision. He can make a recommendation to a department, and if that recommendation is not acted upon he can go to the Prime Minister and thence to Parliament, but it still remains a recommendation, the action in respect of which would in fact ultimately be determined by the Government of the day. This procedure is made effective by the ultimate sanctions of publicity, and of parliamentary and public opinion, to which Government Departments and Agencies are especially responsive. No case has yet occurred where it has been necessary to make an adverse report to the Prime Minister and to Parliament. On the other hand, the departments and agencies are commendably willing to co-operate in the support of the institution, and to accept and give effect to the recommendations of the Ombudsman.

The Act sets out the grounds upon which the Ombudsman may, after making an investigation, make a recommendation or a report. He may do this if the decision which was the subject matter of the investigation appears to him to have been contrary to law, or if it appears to have been based wholly or partly on a mistake of law or fact. He may report if the decision appears to him to have been unreasonable, unjust, oppressive or improperly discriminatory, or if it was in accordance with a rule or law or a provision of any enactment or a practice that is or may be unreasonable, unjust, oppressive or improperly discriminatory. These are wide and sweeping provisions indeed, and the ability to examine the basic equity and justice of the laws and enactments themselves is a matter of great moment. The Ombudsman can never therefore wholly answer a complaint by stating that what has been done has been done in accordance with the law; he is required to go further and satisfy himself that the law itself is fair and just. Such considerations are, of course, of great difficulty, and in the early stages of the experience of the working of the office no very clear lines of practice have emerged, except that from a single adverse case one cannot necessarily assume the injustice of the law itself. Much wider evidence and further investigation is required to establish the inequity of a regulation than to establish a particular case of injustice. Nonetheless, I have had occasion to criticize regulations on one or other of the statutory grounds, and to recommend amendments, which have invariably been made.

Finally, the Ombudsman is empowered to make a recommendation if in his opinion, the decision which was the subject matter of the investigation was "wrong". This elevated use of a plain old English word gives rise to fascinating considerations relating to the applicability of the rules of natural justice, and to the difference between right and wrong on the one hand and lawful and unlawful on the other. Here again no firm rules have been developed, and indeed it would probably be unwise to develop any. It is again a case for an individual decision on the merits of each case, but it is at least worthy of note that the word 'wrong' while undoubtedly including cases of moral turpitude also extends to areas where no moral considerations apply. A certain decision might be just 
plainly wrong on the facts, or it might be a wrong thing to do in a free country.

It is also provided that where a discretionary power is being investigated, the Ombudsman may consider whether the power has been exercised for an improper purpose, or on irrelevant grounds, or on the taking into account of irrelevant considerations, or whether in any case reasons should have been given for the decision.

Having completed his investigation and having formed an opinion that a recommendation is required upon one of the grounds I have mentioned, the Ombudsman then has a wide freedom as to the nature of the recommendation he can make. He may recommend that the matter be referred for further consideration, that the error be rectified, that the decision be cancelled or varied, that any practice on which the decision was based be reconsidered or that any other steps be taken. He may then report his opinion accordingly, and request the department concerned to notify him within a specified time of the steps, if any, that it proposes to take to give effect to his recommendation. If no action is taken then, as I have said, he may, in his discretion, after considering the comments made by or on behalf of the department, send a copy of the report and recommendations to the Prime Minister, and may thereafter make such report to Parliament on the matter as he thinks fit. He is also required to inform the complainant in such manner and at such time as he thinks proper of the result of the investigation.

The Act further provides that he shall make an annual report to Parliament on the exercise of his functions. This reporting power has been supplemented by rules passed by the House authorizing the Ombudsman from time to time, in the public interest or in the interest of any person or department, to publish reports relating generally to the exercise of his functions under the Act or to any particular case or cases investigated by him, whether or not the matters to be dealt with in such report have been the subject of a report to Parliament. Amongst other things this enables the Ombudsman to make periodic statements to the Press.

During the first year of the working of the office a total of $\mathbf{7 8 0}$ complaints were received. Of these 339 were declined for want of jurisdiction or for other reasons, 311 were investigated, and 130 remained under investigation or awaiting investigation at the end of the period. Of the 311 cases which were investigated 68 were determined to be justified for one reason or another. That nearly one-quarter of the investigated complaints should have been found to have been made with good cause is of itself justification for the existence of the institution. This proportion is somewhat higher than that disclosed by the operations of the Danish Ombudsman. Of the 68 complaints that were justified, about one half were rectified by the departments or agencies concerned soon after investigation had begun, showing that in the lower ranks of a large department things can happen which are regarded as questionable when brought to the attention of the head of the department concerned. I should mention that departmental heads have in general shown a broadminded and high-principled willingness to do justice to the cases of individuals, regardless of prior decisions which may have been taken by lower echelons in their departments. 
As to the complaints themselves, there has been a wide variety, covering almost all fields of my jurisdiction.

I mentioned earlier the people's right to know. My investigations have shown that despite an increasing "public relations" consciousness on the part of departments, there is still room for some further change in departmental attitudes towards citizens affected by official actsparticularly where the official act has in the past been final and conclusive. I have had occasion to make recommendations to reverse departmental decisions where the citizen had through ignorance of departmental requirements failed to do something that he could have done if he had known he was expected to do it. Loosely worded circulars, omissions from explanatory pamphlets, and inadequate information by one department of the relevant aspects of another department's contact with the particular circumstances, are cases in point. In some cases it has not been possible to remedy past decisions of this kind, and I could only make recommendations to avoid such situations in the future. The duty to give information does not, however, extend so far as to make it proper for a department actively to espouse a particular point of view in an issue which has by Government policy been deliberately remitted to local electors for their own decision-as in the fluoridation case.

In another case a strong statutory Board had on three separate occasions debated and rejected my complainant's application, but after detailed investigation I was able to convince the Board that it had not appreciated the real merits of her case, and the application was allowed.

The exercise of administrative discretion looms large in the complaints lodged with me. I have had occasion to point out to departments that where matters have been left by statute or otherwise to be dealt with by way of discretionary decision, the discretion must not become submerged in convenient rules of practice tending to reduce administration to routine. On the other hand, in large departments with thousands of individual decisions to be made, there must be rules and directives for the sake of uniformity and efficiency. Much depends upon the spirit with which these rules are administered. The problems surrounding this matter, together with its corollary of administrative delegation, are by no means solved and are still under study.

This leads me to refer to the considerable class of cases which I would categorize 'special'. Most of these are cases of hardship and I have generally found, on referring them to the department concerned, a wholesome readiness to appreciate genuine misfortune and need, and to mitigate the rigours of administration to meet them with reasonable discretionary relief where this is possible. In one case, a New Zealand citizen and his wife embarked on an extensive overseas tour, much of which was to be by car. They bought a car in Singapore, but while touring in it through Ceylon, where it had been admitted on a temporary permit only, the wife became gravely ill and the couple had to abandon their tour and return to New Zealand when the wife was fit to travel. An import licence for the car was at first refused, but when the Comptroller of Customs was convinced of the genuineness of the misfortune and of the seriousness of the problem regarding the disposal of the vehicle, a license was granted. The State Advances Corporation reconsidered a case that came to my notice in which a disabled war pensioner had lost 
a rent concession when he moved into a smaller house, and decided to restore the concession. Another person wrote to me stating that for some time before a period of illness he had been engaged fulltime in voluntary unpaid community work, and accordingly was considered ineligible for a sickness benefit as he had not suffered any loss of earnings. The Department reconsidered the case, and the benefit was granted retrospectively from the time of the onset of the illness. A middle-aged spinster felt she had been forced to resign from the Public Service, but the State Services Commission willingly took her back under different circumstances, and she is now happily placed. Taxation relief on hardship grounds was granted to a man whose wife had deserted him and who had to employ a housekeeper to look after his five children. This type of case gives warm satisfaction.

On the other hand in some classes of benefits, notably Social Security and Housing, there are strict provisions of the law which allow no discretionary exception, and here I am concerned to see that the complainants fully understand the position, and that more general information is available.

Sometimes attempts are made to blame one or more departments for the consequences of personal misfortune, misjudgment, or stupidity. Some very tragic cases of this kind have come to me as a forlorn hope, but unless a scheduled department or organization is at fault I can do nothing except commiserate or sometimes suggest other possible courses of action.

There is, of course, a wide variety of cases of greater complexity, and, some would say, greater importance and interest than those I have mentioned, but time prevents their elaboration here, save to indicate some of the subjects covered:

Government's contractual relations with its servants;

Practice regarding consent to surgical operations;

Unfair difference between two sets of regulations granting education benefits;

Invention of T.A.B. System;

Location of Water-Ski lanes;

Certification of a new type of plum;

Right of a principal of a high school to direct a pupil's course;

Land drainage complications;

Failure of a department to grant approprinte compensation for injuries suffered in course of employment;

Numerous types of claims for social security benefits;

Departmental delays and mistakes of many kinds;

Telephone service in a rural area;

Type certification of aircraft;

Procedure for refund of stamp duties;

Taking of Land;

Leasing of Crown Lands;

Publication by Department of successful tender prices;

Many superannuation complaints;

Confusion between departments;

Rehabilitation and Pension matters;

Tax and Import Licence cases;

Immigration cases;

and so on.

A final point is that many people whose complaints I have had to decide were not justified, have been satisfied to receive a full and careful explanation of the reason why, and to realize that they have perhaps not been so badly treated after all, as they have written and told me. 
Thus we have in New Zealand created yet another institution, which seems to meet a felt need, but we must guard against expecting too much from it, against placing too much reliance upon it for the protection of the citizen's freedom. Let us remember that liberty is offered by the good society, but is achieved and practised by the person. I hope we shall not progress too far in the direction foretold by Lord Radcliffe when he said: -

"The British have formed the habit of praising their institutions which are sometimes inept and of ignoring the character of their race which is often superb. In the end they will be in danger of losing their character and being left with their institutions; a result disastrous indeed."2i 